\title{
Analysis of the Correlation Structure between Stock and Exchange Rate Markets: An Example of China on Asian emerging Markets
}

\author{
Ming-Chieh Wang ${ }^{1} \&$ Sook-Hui Lee ${ }^{1}$ \\ ${ }^{1}$ Department of International Business Studies, National Chi-Nan University, Taiwan \\ Correspondence: Ming-Chieh Wang. Address: Department of International Business Studies, National Chi-Nan \\ University, Puli, 545, Taiwan. Tel: 886-49-2910960-4646.
}

Received: April 11, 2016

Accepted: May 4, 2016

Online Published: May 9, 2016

doi:10.5430/afr.v5n2p104

URL: http://dx.doi.org/10.5430/afr.v5n2p104

\begin{abstract}
This study investigates the dynamic correlation between stock and exchange rate markets to examine the influences of China stock and exchange rate movements on other Asian emerging countries. We employ the GARCH model, which allows for the conditional correlation structure to be time-varying, to explore the return and volatility transmission mechanism between stock and exchange rate markets among these countries. Our results demonstrate that the China stock market has a greater positive impact on other Asian stock markets. We also find that the exchange rate movements of China have a positive effect upon the exchange rate markets of Singapore, South Korea, and Taiwan, but have no significant influence on the other countries. The test of volatility spillover shows that stock market movements do not affect exchange rate markets, which is a result that does not support Phylaktis and Ravazzolo (2005)'s evidence that stock market movements influence the exchange rate dynamics.
\end{abstract}

Keywords: China stock market, China exchange rate market, Dynamic conditional correlation, General Autoregressive Conditional Heteroscedasticity (GARCH) model

\section{Introduction}

China's strong economic growth has greatly influenced the development of Asian emerging economies in recent years. The trade volume between China and these economies increased sharply from US\$161 billion in 2005 to US $\$ 2.977$ trillion in 2010, while Asian financial markets were also affected by the globalization and liberalization of China stock and exchange rate markets. Ahearne et al. (2003) find that the export growth between China and Asian emerging economies exhibits a positive correlation, even after controlling for trading-partner income growth and real exchange rates.

China's government reform of its exchange rate policy on July 21, 2005 has had strong impacts on neighboring countries, because monetary authorities have begun to face coordination failure unless they adjusted their exchange rate policies (Ogawa and Sakane, 2006). Asian emerging markets have also seen a large change in their foreign exchange restrictions, such as adopting flexible exchange rate arrangements. For example, the Malaysian government adjusted its exchange rate system from pegging its currency to the U.S. dollar to a currency basket on the same day that the Chinese government did. Exchange rate volatilities have increased in Asian emerging markets, and as stock markets have also become more correlated to foreign exchange markets, the investment risk in these markets has risen. Because the interaction between foreign exchange rate and stock markets is important for international investors, this study therefore investigates the correlations of stock and exchange rate markets between China and emerging Asia markets.

Many recent studies have focused on different aspects of financial services industry in emerging economies (Riasi and Aghdaie, 2013). This is mainly due to the structural differences in exchange and stock markets of emerging economies compared to the more developed economies (Riasi, 2015). Furthermore, several papers focus on foreign exchange and stock markets in emerging countries. Jorion (1990) shows that a moderate relationship exists between the stock returns of U.S. multinational companies and the effective exchange rates of the U.S. dollar in the 1971-1987 period. Smyth and Nandha (2003) also indicate that there is no long-run relationship between exchange rates and stock prices. Chiang and Yang (2003) show that stock returns and exchange rates are positively related for nine Asian markets. However, these studies are generally based on the first moments in the specification of the dynamic relationship between exchange rates and stock prices ${ }^{1}$. In recent year, Pan et al. (2007) show mixed 
relationships between the two markets in seven East Asia countries before the Asian financial crisis, but currency values have a strong effect on stock prices during the Asian crisis. Zhao (2010) finds the bidirectional volatility spillover effects between two markets in China by using Multivariate General Autoregressive Conditional Heteroscedasticity model (M-GARCH). Moorea and Wang (2014) find the trade balance is the important factor to determine the dynamic relationship between real exchange rates and stock return differentials in relation to the U.S. market for the developed and Asian emerging markets. Chkili and Nguyen (2014) use the Markov switching VAR models to examine the Brazil, Russia, India, China and includes South Africa (BRICS) countries and show that the unilateral impact from stock market to foreign exchange market. Sui and Sun (2016) find that there are stronger spillover effects between exchange rates and stock returns for the BRICS countries during the 2008 global financial crisis.

Many researchers have long been interested in volatility spillover between exchange rates and stock prices. Analysis of volatility spillover can indicate the information transmission mechanisms in these two markets. Based on the GARCH framework, several studies have examined the volatility spillover for the varying nature of financial assets. For instance, Kanas (2000) demonstrates an asymmetric volatility spillover from stock returns to exchange rates in the United States, the United Kingdom, Japan, France, and Canada. Yang and Doong (2004) examine the mean and volatility transmission between stock prices and exchange rates for developed countries, suggesting that an asymmetric volatility spillover effect exists, and that the movements of stock prices affect future exchange rate dynamics. Phylaktis and Ravazzolo (2005) use the dynamic conditional correlation (DCC) structure for the returns and volatilities of stock and exchange rate markets, noting that the two markets are positively correlated and U.S. stock markets act as a conduit for these links, but the links are not determined by exchange rate restrictions

The literature has frequently discussed the relationship between stock and exchange rate markets. On the basis of previous findings - some of which support the positive relationship between stock and exchange rate markets whereas others do not - the present study applies the model of Phylaktis and Ravazzolo (2005) to examine the relationships of stock and exchange rate markets between China and Asian emerging countries according to the dynamic correlations of return and volatility. As the literature seldom has addressed the shared effects of China on the sample countries, this study fills the gap by showing the relationship between stock prices and exchange rates in two ways. First, this study focuses on the relationship between the stock and exchange rate markets in China and the selected Asian emerging countries. Second, this study models return and volatility under the assumption of a conditional correlation structure and then investigates the impact of China's stock and exchange rate market movements on the other Asian countries.

The findings herein do show significant spillover effects, suggesting stock and exchange rate volatility in the China market does impact other Asian countries. Additionally, we do not find significant positive relationships between the exchange rates and stock returns. Thus, the exchange rate market does not necessarily support the result of Phylaktis and Ravazzolo (2005) whereby stock and exchange rate markets are positively correlated.

The remainder of this paper is organized as follows. Section 2 describes the methodology. Section 3 presents the empirical results. Section 4 provides a brief summary and implications.

\section{Methodologies}

This study looks at the dynamic correlation structure for the returns and volatilities of stock and exchange rate markets between China and Asian emerging markets. Engle (2002) proposes the DCC-GARCH model to investigate the dynamics correlation between the returns of DJIA and NASDAQ stock indices and shows that their correlations are time-varying. The DCC model formulates the conditional correlation as a weighted sum of past correlations and allows the conditional correlation matrix to be time-dependent. Assume the multivariate GARCH model has a $k \times 1$ vector of asset returns $y_{t}$ exhibiting a conditional normal distribution of zero mean and covariance matrix $H_{t}$ :

$$
y_{t} \mid \Omega_{t-1} \sim N\left(0, H_{t}\right),
$$

where $\Omega_{t-1}$ is the information set at time $t-1$. Under the DCC-GARCH framework, we define the covariance matrix as:

$$
H_{t} \equiv D_{t} R_{t} D_{t}
$$


where $D_{t}=\operatorname{diag}\left\{\sqrt{h_{i t}}\right\}$ is a $k \times k$ diagonal matrix of time-varying standard deviations from univariate GARCH models with $\sqrt{h_{i t}}$ on the $i$ th diagonal, and $\left.R_{t} \equiv \rho_{i j}\right\}_{t}$ is the time varying correlation matrix by considering conditional correlation effects. The univariate $\operatorname{GARCH}(p, q)$ is given as:

$$
h_{i t}=w_{i}+\sum_{q=1}^{q_{i}} \alpha_{i p} \varepsilon_{i t-p}^{2}+\sum_{p=1}^{p_{i}} \beta_{i q} h_{i t-q} .
$$

The estimation of the DCC-GARCH model is obtained by:

$$
R_{t}=Q_{t}^{*-1} \mathrm{Q}_{\mathrm{t}} \mathrm{Q}_{\mathrm{t}}^{*-1}
$$

where the evolution of the correlation in the model is given by:

$$
Q_{t}=\left(1-\sum_{m=1}^{M} \alpha_{m}-\sum_{n=1}^{N} \beta_{n}\right) \bar{Q}+\sum_{m=1}^{M} \alpha_{m}\left(\xi_{t-m} \xi_{t-m}\right)+\sum_{n=1}^{N} \beta_{n} Q_{t-n},
$$

$\xi_{t}=\frac{\varepsilon_{i t}}{h_{i t}}$ is a vector that includes the standard residuals, and $\varepsilon_{t} \sim N\left(0, R_{t}\right), \bar{Q}$ is the unconditional variance matrix of $\xi_{t-m}, Q_{t} \equiv\left\{q_{i j}\right\}_{t}$ is regarded as a conditional variance-covariance matrix. $Q_{t}^{*}$ is a $k x k$ diagonal matrix containing the square root of the diagonal elements of $Q_{t}$ :

The dynamic correlation specification is

$$
Q_{t}^{*}=\left[\begin{array}{cccc}
\sqrt{q_{11}} & 0 & \cdots & 0 \\
0 & \sqrt{q_{22}} & \cdots & 0 \\
\vdots & \cdots & \ddots & 0 \\
0 & 0 & \cdots & \sqrt{q_{k k}}
\end{array}\right]
$$

$$
h_{i, t}=\rho_{i, 0} *\left\lfloor\sqrt{h_{i, t}} \sqrt{h_{C N, t}}\right\rfloor
$$

for China and the other countries in their stock and exchange rate markets.

This study utilizes the DCC-GARCH $(1,1)$ model to examine the relationship of stock and exchange rate markets for China and other Asian emerging countries. This relationship for China stock and exchange rate markets is expressed as follows:

$$
\begin{aligned}
& P_{c n, t}=\theta_{c n}+\theta_{1} P_{c n, t-1}+\theta_{2} P_{i, t-1}+\theta_{3} E_{c n, t-1}+u_{c n, t}, \\
& E_{c n, t}=\delta_{c n}+\delta_{1} E_{c n, t-1}+\delta_{2} P_{c n, t-1}+\delta_{3} E_{i, t-1}+\varepsilon_{c n, t} .
\end{aligned}
$$

The other emerging stock and exchange rate markets are expressed as:

$$
\begin{aligned}
& P_{i, t}=\theta_{i}+\sum_{n=1}^{p} \theta_{i, 1}^{n} P_{i, t-n}+\theta_{i, 2} P_{c n, t-1}+\theta_{i, 3} E_{c n, t-1}+\theta_{i, 4} E_{i, t-1}+u_{i, t}, \\
& E_{i, t}=\delta_{\mathrm{i}, 0}+\sum_{n=1}^{p} \delta_{\mathrm{i}, 1}^{\mathrm{n}} \mathrm{E}_{\mathrm{i}, \mathrm{t}-\mathrm{n}}+\delta_{i, 2} \mathrm{E}_{\mathrm{cn}, \mathrm{t}-1}+\delta_{\mathrm{i}, 3} \mathrm{P}_{\mathrm{cn}, \mathrm{t}-1}+\delta_{i, 4} P_{i, t-1}+\varepsilon_{i, t} .
\end{aligned}
$$

Equations (8) to (11) are the conditional mean model for the stock and exchange rate markets of China and the Asian countries, respectively. Let $P_{c n, t}$ and $P_{i, t}\left(E_{c n, t}\right.$ and $E_{i, t}$ ) represent the daily stock market (exchange rate) returns of China and emerging market i. For the China market's model specification in Equations (8) and (9), the conditional mean equation of the China stock market (exchange rate market) returns depend on a constant term, the China and emerging stock returns (exchange rate returns) at time $\mathrm{t}-1$, and the exchange rate (stock) return of China at time $\mathrm{t}-1$, where $u_{C N, t}$ and $\varepsilon_{C N, t}$ are the innovations of China stock and exchange rate returns, respectively. Similarly, we assume the stock (exchange rate) return of an emerging market are affected by the lag returns of domestic stock and exchange rate returns, China stock and exchange rate returns, and other emerging stock (exchange rate) return in Equations (10) and (11).

Under the assumption of the conditional normality for the random error, $u_{t}$, we rewrite the maximum log likelihood function for estimating the DCC-GARCH model's parameters as: 


$$
L=-\frac{1}{2} \sum_{t=1}^{T}\left(n \log (2 \pi)+2 \log \left|\mathrm{D}_{\mathrm{t}}\right|+\log \left|\mathrm{R}_{\mathrm{t}}\right|+\varepsilon_{\mathrm{t}}^{\prime} \mathrm{R}_{\mathrm{t}}^{-1} \varepsilon_{\mathrm{t}}\right)
$$

The general restriction of non-negativity and stationarity of variances are assumed. The DCC model is estimated using a three-stage procedure. First, the univariate $\operatorname{GARCH}(p, q)$ models with $p=q=1$ are fitted into the two series, and the estimated standard residuals can then be obtained. The second stage involves an estimation of the intercept parameters of conditional correlation. Finally, the coefficients governing the dynamics of correlation are estimated using the intercept parameters of conditional correlation.

The innovation distribution in practice may not expect to be normally distributed. Thus the maximum likelihood estimation may yield an inappropriate standard error when the innovations exhibit non-normality. Bollerslev and Wooldridge (1992) propose the robust variance-covariance matrix estimator to non-normality, and the maximum likelihood approach with the standard error is described as the quasi-maximum likelihood (QML). Therefore, we use QML to estimate the parameters for the non-normality property of bond returns. The estimated parameters for non-normality returns can be derived by maximizing Equation (12) and then using the robust standardize residual.

\section{Empirical Results}

\subsection{Data}

This paper collects the data from the DataStream database, and the stock price and exchange rates are on a daily basis. Because the Chinese government reformed its exchange rate policy on July 21, 2005, our sample period is from August 1, 2005 to July 31, 2012, in order to examine the influences of the China exchange rate movements on other Asian emerging countries having a more floating exchange rate system. Our selected countries consist of major Asian emerging countries, including China, India, Malaysia, Philippines, Singapore, South Korea, Taiwan, Thailand, and Vietnam.

To explore the dynamic relationships, instrumental variables are used such as the major stock indices and exchange rates for China and other Asian emerging countries. Table 1 contains the summary statistics for stock index returns. The averages range from the lowest $0.0168 \%$ (Taiwan) to highest $0.0689 \%$ (India), and the standard deviations range from the lowest $1.45 \%$ (Malaysia) to highest $3.71 \%$ (China). The result shows that China has the greatest investment risk, while Malaysia has the lowest. All returns' series distributions are skewed to the left, except India and South Korea, and the kurtosis statistics are all greater than 3. Both Skewness and Kurtosis statistics suggest that the negative shocks are stronger than positive shocks in emerging markets, except that the Vietnam stock return series do not fit the pattern. The result is also confirmed by the Jarque-Bera statistics, except for Vietnam. Here the rejection of the null hypothesis of zero and excess kurtosis for all returns reflects non-normal distribution properties of all returns.

Table 2 contains the summary statistics for the daily returns of exchange rates. The average returns over the sample period range from the lowest $-0.0138 \%$ (Thailand) to highest $0.0083 \%$ (Vietnam), while the standard deviations range from the lowest $0.0813 \%$ (China) to highest $1.0564 \%$ (Vietnam). The result shows that the

Table 1. Description statistics of the stock index returns

\begin{tabular}{lcccccc}
\hline Country & Stock Index & Mean & Std. & Skewness & Kurtosis & Jarque-Bera \\
\hline China & Shanghai A Stock & 0.0661 & 3.7154 & -2.2054 & 28.88 & 34807.76 \\
India & BSE Sensex & 0.0689 & 1.9668 & 0.0901 & 8.722 & 1676.30 \\
Malaysia & FTSE Bursa Malaysia KLCI & 0.0299 & 1.4585 & -0.1200 & 86.83 & 363697.70 \\
Philippines & Philippines Stock Exchange & 0.0450 & 1.6288 & -0.5631 & 14.74 & 7054.13 \\
Singapore & Straits Times Index & 0.0186 & 1.4737 & -0.3149 & 8.161 & 1414.29 \\
South Korea & iShares MSCI South Korea Index & 0.0236 & 2.7381 & 0.5606 & 13.02 & 5336.33 \\
Taiwan & TSEC weighted index & 0.0168 & 1.4869 & -0.3675 & 5.42 & 330.33 \\
Thailand & Thailand Set Index & 0.0197 & 1.5712 & -1.0732 & 17.45 & 10695.7 \\
Vietnam & Vietnam Stock Index & 0.0563 & 1.9570 & -0.0918 & 3.013 & 175.55 \\
\hline
\end{tabular}

Notes: The stock returns are calculated from daily observations on China and the eight Asian countries covering August 1, 2005 to July, 31, 2010. 
Table 2. Description statistics of the exchange rate returns

\begin{tabular}{lcccccccc}
\hline Country & Currency & Mean & Max & Min & Std. & Skewness & Kurtosis & Jarque-Bera \\
\hline China & Ren Min Bi & -0.0098 & 0.8875 & -0.8889 & 0.0813 & -0.0481 & 28.5730 & 49730 \\
Indonesia & Indonesian Rupiah & -0.0048 & 8.1211 & -5.5043 & 0.7085 & 1.1372 & 28.5736 & 50125 \\
Malaysia & Malaysian Ringgit & -0.0089 & 5.4724 & -8.5054 & 0.8509 & -0.4805 & 16.8992 & 14760 \\
Philippines & Philippine Peso & -0.0115 & 4.8322 & -4.6914 & 0.4751 & 0.2315 & 22.9341 & 30232 \\
Singapore & Singapore Dollar & -0.0110 & 1.2962 & -1.5363 & 0.2377 & -0.2070 & 8.3694 & 2205 \\
South Korea & Korean Won & 0.0078 & 9.4793 & -9.7422 & 1.0355 & -0.4021 & 15.6641 & 12244 \\
Taiwan & Taiwan Dollar & 0.0001 & 2.2604 & -2.6037 & 0.2619 & -0.5971 & 16.0828 & 13123 \\
Thailand & Thai Baht & -0.0138 & 6.6369 & -6.1941 & 0.5614 & 0.7223 & 33.8928 & 72730 \\
Vietnam & Vietnamese Dong & 0.0083 & 6.9572 & -5.6332 & 1.0564 & 0.0058 & 8.8831 & 2631
\end{tabular}

Notes: The exchange rate returns are calculated from daily observations on China and the eight sample countries ranging from August 1, 2005 to July, 31, 2010.

greatest exchange rate investment risk is in Vietnam and the lowest is in China. All returns series distributions are skewed to the left except India, Philippines, Thailand, and Vietnam, and the kurtosis statistics are greater than 7. Both Skewness and Kurtosis statistics suggest that negative shocks from exchange rate movements occur more often than positive shocks. In general, the distributions for all series exhibit leptokurtosis, which is also confirmed by the Jarque-Bera statistics for rejecting the null hypothesis of normal distribution.

\subsection{Correlation Structure}

To measure the economic linkage between China and the Asian emerging markets, Table 3 reports the dynamic conditional correlation for these stock markets. In this table, the lowest correlation with China is Vietnam (-0.160) and the highest is Thailand (0.734). The average correlation between China and the other markets is 0.121 , and the correlations are all significant. We find that positive correlations are high, but negative correlations are trivial, meaning we can see the return spillover effects from China to the emerging markets. Similarly, we also note the cross correlations are statistically significant and mostly positive, supporting that return spillover exists in Asian markets.

Table 4 reports the dynamic conditional correlations of exchange rate movements for these markets. In this table, the lowest correlation with China is Vietnam (-0.715) and the highest correlation is the Philippines (0.489). The average correlation between China and the emerging markets is -0.054 . The contemporaneous correlation of China exchange rate returns with South Korea is not statistically significant, whereas the mean spillover effects are significant in these markets but their directions are not parallel.

\subsection{Diagnostic Tests}

Table 5 presents the Augment Dickey-Fuller (ADF) unit root test in which that all returns series are stationary. For the model specification in the GARCH model, the criterion used to choose the appropriate lags for the

Table 3. Dynamic correlations of GARCH $(1,1)$ for stock returns

\begin{tabular}{l|l|l|l|l|l|l|l|l|l}
\hline & China & India & Malaysia & Philippines & Singapore & South Korea & Taiwan & Thailand & Vietnam \\
\hline China & 1.00 & & & & & & & \\
\hline India & $0.252 * * *$ & 1.00 & & & & & & \\
\hline Malaysia & $0.631 * * *$ & $-0.154 * * *$ & 1.00 & & & & & \\
\hline Philippines & $-0.075 * * *$ & $0.088 * * *$ & $0.231 * * *$ & 1.00 & & & & \\
\hline Singapore & $-0.208 * * *$ & 0.212 & $-0.153 * * *$ & $-0.217 * * *$ & 1.00 & & & \\
\hline South Korea & $-0.056 * * *$ & $0.132 * * *$ & $0.104 * * *$ & $0.588 * * *$ & $0.622 * * *$ & 1.00 & & \\
\hline Taiwan & $-0.039 * * *$ & -0.037 & $0.671 * * *$ & $0.031 * * *$ & $-0.039 * * *$ & -0.0804 & 1.00 & & \\
\hline Thailand & $0.734 * * *$ & $0.513 * * *$ & $0.576 * * *$ & $0.150 * * *$ & $0.123 * * *$ & $0.303 * * *$ & $0.456 * * *$ & 1.00 & \\
\hline Vietnam & $-0.160 * * *$ & -0.056 & $-0.220 * * *$ & $-0.516 * * *$ & $-0.003 * * *$ & $-0.043 * * *$ & $0.357 * * *$ & -0.008 & 1.00 \\
\hline
\end{tabular}

Note: $* * *$ indicates significance at the $1 \%$ level. 
Table 4. Dynamic constant correlations of GARCH $(1,1)$ for exchange rate returns

\begin{tabular}{l|l|l|l|l|l|l|l|l|l}
\hline & \multicolumn{1}{|c|}{ China } & \multicolumn{1}{|c|}{ India } & Malaysia & Philippines & Singapore & $\begin{array}{l}\text { South } \\
\text { Korea }\end{array}$ & Taiwan & Thailand & Vietnam \\
\hline China & 1.00 & & & & & & & & \\
\hline India & $0.250 * * *$ & 1.00 & & & & & & & \\
\hline Malaysia & $-0.646 * * *$ & $-0.220 * * *$ & 1.00 & & & & & & \\
\hline Philippines & $0.489 * * *$ & $0.179 * * *$ & $-0.882 * * *$ & 1.00 & & & & & \\
\hline Singapore & $-0.489 * *$ & -0.225 & $-0.764 * * *$ & $-0.275 * * *$ & 1.00 & & & & \\
\hline South Korea & -0.011 & -0.084 & $-0.570 * * *$ & $-0.116 * * *$ & $-0.224 *$ & 1.00 & & & \\
\hline Taiwan & $-0.056 * * *$ & $-0.167 * *$ & $-0.684 * * *$ & $-0.116 * * *$ & $-0.603 * * *$ & -0.108 & 1.00 & & \\
\hline Thailand & $0.196 * * *$ & 0.073 & $-0.360 * * *$ & -0.026 & -0.063 & $0.070 *$ & -0.063 & 1.00 & \\
\hline Vietnam & $-0.715 * * *$ & -0.076 & $-0.860 * * *$ & $-0.091 * * *$ & -0.004 & -0.067 & -0.061 & 0.009 & 1.00
\end{tabular}

Note: $* *$ and $* * *$ indicates significance at the $5 \%$, and $1 \%$ levels, respectively.

ARMA model are Akaike's Information Criterion (AIC) and Schwarz's Criterion (SIC). The Ljung-Box Q statistics for 5 and 10 lags are calculated for both the return and squared residuals. In this table the Ljung-Box Q statistics are statistically insignificant for all returns series providing no evidence of linear dependence in the residuals. However, the Ljung-Box $\mathrm{Q}^{2}$ statistics for the squared returns are statistically significant for all squared return series, showing that all squared returns series are strongly serial correlated and suggesting the possibility of the presence of autoregressive conditional heteroscedasticity. To correct the serial correlation shown in the squared residuals, the GARCH model is suitable for this study. Moreover, the ARCH Lagrange multiplier (LM) test confirms the existence of ARCH effects in these markets. Jarque-Bera (JB) statistics for the normality test reveal a non-normal distribution in the returns series.

Table 5. Diagnostic test for the residuals of the log difference stock returns

\begin{tabular}{lccccccc}
\hline & $\mathrm{ADF}$ & $\mathrm{Q}(5)$ & $\mathrm{Q}(10)$ & $\mathrm{Q}^{2}(5)$ & $\mathrm{Q}^{2}(10)$ & $\mathrm{JB}$ & $\mathrm{ARCH}-\mathrm{LM}(7)$ \\
\hline China & $-34.1514 * * *$ & 3.3615 & 9.0838 & $5.7953 * *$ & $6.5828 * *$ & $31082.5600 * * *$ & $9.3023 * * *$ \\
India & $-32.5656 * * *$ & 1.1290 & 10.7100 & $133.9087 * * *$ & $252.1381 * * *$ & $1603.9350 * * *$ & $9.6642 * * *$ \\
Malaysia & $-45.9960 * * *$ & 0.4800 & 2.3166 & $215.8014 * * *$ & $216.1199 * * *$ & $197207.2000 * * *$ & $1.3233 * * *$ \\
Philippines & $-33.1702 * * *$ & 5.6336 & 9.5897 & $106.1119 * * *$ & $119.2799 * * *$ & $7197.3420 * * *$ & $5.1995 * * *$ \\
Singapore & $-35.8722 * * *$ & 1.8753 & 6.7005 & $356.9396 * * *$ & $635.7600 * * *$ & $1224.9290 * * *$ & $1.9754 * * *$ \\
South Korea & $-38.7303 * * *$ & 3.4401 & 18.1373 & $642.2384 * * *$ & $1208.8602 * * *$ & $5107.9140 * * *$ & $9.0063 * * *$ \\
Taiwan & $-33.3241 * * *$ & 0.7753 & 8.7951 & $176.5504 * * *$ & $290.0102 * * *$ & $274.4352 * * *$ & $6.7257 * * *$ \\
Thailand & $-22.4477 * * *$ & 3.6837 & 8.5830 & $150.4375 * * *$ & $162.6742 * * *$ & $11262.6500 * * *$ & $5.2688 * * *$ \\
Vietnam & $-14.2898 * * *$ & 16.0259 & 19.8546 & $242.8802 * * *$ & $400.1487 * * *$ & $4.5192 * * *$ & $16.0249 * *$
\end{tabular}

Notes: This table presents residual diagnostic test. ARMA (p, q) is chosen based on the AIC/SBC. The Ljung-Box test statistics $\mathrm{Q}(5)$ and $\mathrm{Q}(10)$ test for autocorrelation in the residual to lag 5 and to lag 10, respectively. The squared residuals for $\mathrm{Q}^{2}(5)$ and $\mathrm{Q}^{2}(10)$ test for the Jarque-Bera statistics for the normality test. The ADF's unit root test is for testing the existence of a unit root in the series, and the ARCH-LM test is for testing the ARCH effect with 7 lags. ** and $* * *$ denote significance at the $5 \%$, and $1 \%$ level, respectively.

\subsection{The Effect of Stock Markets between China and Asian Emerging Countries}

This research uses the DCC-GARCH $(1,1)$ model to analyze the dynamic relationship among China and the Asian emerging markets for exchange rates and stock prices. Table 6 presents the results of stock markets. Panel A shows the coefficient estimates of the conditional mean equation for Singapore, South Korea, and Taiwan, where these three markets are more developed and have high economic linkages with China in Asia. We find the China stock market has significant effect on these three stock markets, while its exchange rate also has a significant effect on the stock markets for Singapore and Taiwan. The negative impact on the stock markets of South Korea and Taiwan is because the two markets are heavily dependent on China for sourcing many IT products; therefore, the dynamic 
conditional correlation is higher than it is for Singapore, and capital flows may be highly active between China and these two markets. Panel B shows the results for other countries, and we find that the China stock market has a significantly negative shock on Thailand and Philippines, and a significantly positive shock on India, Malaysia and Vietnam. The dynamic conditional correlations are all positive for the stock markets of China and these countries.

For the influence of China's exchange rate on Asian stock markets, its effect is higher than the China stock market and positively impacts Singapore, India, Malaysia, Philippines, and Vietnam, while negatively impacting South Korea, Taiwan, and Thailand. Therefore, we conclude that Asian emerging markets are integrated with the China stock markets, and most stock markets are also influenced from China's exchange rate movements, thus supporting a relationship between the stock and exchange rate markets.

Table 6. Effect of stock markets between China and Asian emerging countries

Panel A: Stock returns of Singapore, South Korea and Taiwan

\begin{tabular}{|c|c|c|c|c|c|c|c|c|}
\hline $\begin{array}{l}\text { Conditional } \\
\text { mean equation }\end{array}$ & $\mathrm{P}_{\mathrm{cn},-1}$ & $\mathrm{E}_{\mathrm{cn},-1}$ & $\mathrm{P}_{\mathrm{EM},-1}$ & $\mathrm{P}_{\mathrm{EM},-2}$ & $\mathrm{E}_{\mathrm{EM},-1}$ & $\begin{array}{l}\text { Conditional } \\
\text { variance equation }\end{array}$ & $u_{t-1}^{2}$ & $h_{t-1}$ \\
\hline China & -0.055 & -10.36 & -0.351 & & & & $-0.095 * * *$ & $0.512 * * *$ \\
\hline Singapore & $0.123 *$ & $3.911 * *$ & $-0.088 *$ & -0.012 & 0.167 & & $-0.074 * * *$ & $0.372 * * *$ \\
\hline China & -0.066 & $3.699 * *$ & 0.176 & & & & $-0.160 * * *$ & $0.592 * * *$ \\
\hline South Korea & $-0.055^{*}$ & -10.36 & -0.351 & -0.019 & 0.000 & & $-0.095 * * *$ & $0.512 * * *$ \\
\hline China & -0.123 & $-3.91 *$ & -0.088 & & & & $-0.074 * * *$ & $0.3722 * * *$ \\
\hline Taiwan & $-0.057 *$ & $-12.10 *$ & $-0.128 * *$ & -0.027 & 0.001 & & $-0.087 * * *$ & $0.1263 * * *$ \\
\hline
\end{tabular}

Dynamic conditional correlation

China vs. Singapore $-0.019 * *$

China vs. South Korea 0.115

China vs. Taiwan $0.074 *$

Note: *,**, and *** indicates significance at the $10 \%, 5 \%$, and $1 \%$ levels, respectively

Panel B: Stock returns of other Asian emerging countries

\begin{tabular}{|c|c|c|c|c|c|c|c|c|}
\hline $\begin{array}{l}\text { Conditional } \\
\text { mean equation }\end{array}$ & $\mathrm{P}_{\mathrm{cn},-1}$ & $\mathrm{E}_{\mathrm{cn},-1}$ & $\mathrm{P}_{\mathrm{EM},-1}$ & $\mathrm{P}_{\mathrm{EM},-2}$ & $\mathrm{E}_{\mathrm{EM},-1}$ & $\begin{array}{l}\text { Conditional } \\
\text { variance equation }\end{array}$ & $u_{t-1}^{2}$ & $h_{t-1}$ \\
\hline China & -0.079 & -10.57 & -0.002 & & & & $-0.086 * * *$ & $0.459 * * *$ \\
\hline India & $0.106^{*}$ & $13.12 * * *$ & 0.131 & -0.486 & 0.061 & & $-0.125 * * *$ & $0.449 * * *$ \\
\hline China & -0.008 & -11.15 & 0.974 & & & & $-0.076 *$ & $0.390 * *$ \\
\hline Malaysia & $0.009 * *$ & $0.892^{* *}$ & $-0.065^{*}$ & -0.048 & $-0.213^{*}$ & & $-0.162 * * *$ & $0.875 * * *$ \\
\hline China & -0.073 & -9.391 & 0.324 & & & & $-0.079 *$ & $0.591 *$ \\
\hline Philippines & $-0.066^{*}$ & $3.699 *$ & $0.176^{*}$ & -0.199 & 0.001 & & $-0.160 *$ & $0.592 *$ \\
\hline China & 0.070 & -7.090 & -0.221 & & & & $-0.202 * * *$ & $0.543 * * *$ \\
\hline Thailand & $-0.035 * *$ & $-12.75^{* *}$ & $-0.225^{*}$ & 0.229 & 1.426 & & $-0.092 * * *$ & $0.535 * * *$ \\
\hline China & -0.112 & $-13.23^{*}$ & 0.326 & & & & $-0.097 * * *$ & $0.523 * * *$ \\
\hline Vietnam & $0.858 *$ & $0.244^{*}$ & 0.206 & 0.129 & 0.848 & & $0.159 *$ & $0.058 *$ \\
\hline
\end{tabular}

Dynamic conditional correlation

China vs. India $0.002 * * *$

China vs. Malaysia $0.413 * * *$

China vs. Philippines $0.257 *$

China vs. Thailand $0.116^{* * * *}$

China vs. Vietnam $0.001 *$

Note: $* * *$, and $* * *$ indicates significance at the $10 \%, 5 \%$, and $1 \%$ levels, respectively. 


\subsection{Effect of exchange rate markets between China and Asian emerging Countries}

For the exchange rate markets, Table 7 shows the estimated results with dynamic conditional correlation, and the coefficients are all positive and statistically significant for all markets. In Panel A, the stock market of China

Table 7. Effect of exchange rate markets between China and Asian Countries

Panel A: Exchange rate returns of Singapore, South Korea and Taiwan

\begin{tabular}{|c|c|c|c|c|c|c|c|c|}
\hline $\begin{array}{l}\text { Conditional } \\
\text { mean equation }\end{array}$ & $P_{c n,-1}$ & $\mathrm{E}_{\mathrm{cn},-1}$ & $\mathrm{P}_{\mathrm{EM},-1}$ & $\mathrm{P}_{\mathrm{EM},-2}$ & $\mathrm{E}_{\mathrm{EM},-1}$ & $\begin{array}{l}\text { Conditional } \\
\text { variance equation }\end{array}$ & $u_{t-1}^{2}$ & $\mathrm{~h}_{t-1}$ \\
\hline China & 0.001 & -0.166 & & $0.058 * *$ & & & $-0.109^{*}$ & $1.162 * *$ \\
\hline Singapore & 0.017 & $0.514 * * *$ & 0.023 & 0.211 & 0.006 & & $-0.069 * * *$ & $0.567 * * *$ \\
\hline China & 0.002 & $-0.144^{*}$ & & 0.001 & & & $-0.149 * *$ & $1.169 * * *$ \\
\hline South Korea & -0.001 & -0.567 & $-0.012^{*}$ & $0.428 * *$ & 0.062 & & $1.224 *$ & $-0.034 *$ \\
\hline China & -0.002 & $-0.136 * *$ & & 0.015 & & & $-0.109 * * *$ & $1.102 * * *$ \\
\hline Taiwan & $-0.010 * *$ & $0.904 * *$ & 0.004 & $0.029 *$ & 0.024 & & $0.052 * * *$ & $0.705^{* * *}$ \\
\hline
\end{tabular}

Dynamic conditional correlation

\begin{tabular}{ll}
\hline China vs. Singapore & $0.493 * * *$ \\
China vs. South Korea & $0.114 *$ \\
China vs. Taiwan & $0.057 * * *$
\end{tabular}

Note: $*, * *$, and $* * *$ indicates significance at the $10 \%, 5 \%$, and $1 \%$ levels, respectively.

Panel B: Exchange rate returns of Asian emerging countries

\begin{tabular}{|c|c|c|c|c|c|c|c|c|}
\hline $\begin{array}{l}\text { Conditional } \\
\text { mean equation }\end{array}$ & $P_{\mathrm{cn},-1}$ & $\mathrm{E}_{\mathrm{cn},-1}$ & $\mathrm{P}_{\mathrm{EM},-1}$ & $\mathrm{E}_{\mathrm{EM},-1}$ & $\mathrm{E}_{\mathrm{EM}-2}$ & $\begin{array}{l}\text { Conditional } \\
\text { variance equation }\end{array}$ & $u_{t-1}^{2}$ & $h_{t-1}$ \\
\hline China & 0.002 & -0.138 & & 0.003 & & China & $-0.002 * * *$ & $0.002 * * *$ \\
\hline India & -0.036 & $1.568^{*}$ & $-0.121 *$ & $-0.105^{* *}$ & 0.078 & India & $0.276 * * *$ & $0.779 * * *$ \\
\hline China & $0.001^{*}$ & -0.126 & & $0.053^{*}$ & & China & $-0.157 * * *$ & $1.148 * * *$ \\
\hline Malaysia & -0.007 & 0.060 & $-0.017 * * *$ & $-0.354 * * *$ & 0.085 & Malaysia & $0.150 * * *$ & $-1.049 * * *$ \\
\hline China & -0.001 & -0.134 & & -0.011 & & China & $-0.168 * *$ & $1.163 * * *$ \\
\hline Philippines & $0.002 * *$ & -0.330 & 0.031 & -0.113 & 0.117 & Philippines & $-0.143 * * *$ & $1.098 * * *$ \\
\hline China & 0.002 & $-0.227 * *$ & & 0.020 & & China & $-0.086^{* * *}$ & $1.113 * * *$ \\
\hline Thailand & 0.041 & $-0.676^{*}$ & -0.036 & 0.121 & 0.134 & Thailand & $0.0505^{* * *}$ & $0.813 * * *$ \\
\hline China & 0.001 & -0.169 & & 0.002 & & China & $-0.130 * * *$ & $1.133 * * *$ \\
\hline Vietnam & -0.019 & -4.716 & 0.066 & $-0.103 *$ & 0.157 & Vietnam & $0.020 * * *$ & $1.787 * * *$ \\
\hline \multicolumn{9}{|c|}{ Dynamic conditional correlation } \\
\hline \multicolumn{9}{|c|}{$\begin{array}{ll}\text { China vs. India } 0.002^{* * *} \\
\end{array}$} \\
\hline \multicolumn{9}{|c|}{ China vs. Malaysia $0.001 *$} \\
\hline \multicolumn{9}{|c|}{ China vs. Philippines $\quad 0.004 * * *$} \\
\hline \multicolumn{9}{|c|}{ China vs. Thailand $0.015^{* *}$} \\
\hline \multicolumn{9}{|c|}{ China vs. Vietnam $0.002^{*}$} \\
\hline
\end{tabular}

Note: $*, * *$, and $* * *$ indicates significance at the $10 \%, 5 \%$, and $1 \%$ levels, respectively.

only has a significantly negative effect on the exchange rate of Taiwan, because when China's stock market is declining, foreign investors may move their funds to invest in Taiwan and push the Taiwan currency to appreciate. In addition, China's currency has a positive effect on Singapore's exchange rate, because when China's currency appreciates, China has more money to buy oversea production, which may affect import countries' currency to appreciate in long run. In Panel B, the China stock market only has a significantly positive effect on exchange rate of 
the Philippines; and the exchange rate of China has a significantly positive (negative) effect on the exchange rate of India (Thailand).

We therefore conclude that the China exchange rate market is integrated with the exchange rate markets for the more developed countries of Singapore, South Korea and Taiwan. However, the stock market of China does not have any significant effect on most exchange rate markets, which does not support Yang and Doong's (2004) evidence that the movement of stock indices will affect future exchange rate dynamics.

\subsection{Model Diagnostic}

Table 8 depicts the results of the model diagnostic statistics of standardized residuals for stock and exchange rate returns under the GARCH $(1,1)$ model. We test for whether the model's specification is correct by employing the Ljung-Box test. If the model is well specified, then the p-value should not exceed the confidence level, meaning that the conditional variance equations enable us to capture the autoregressive heteroscedasticity of the return series. The results in Panel A suggest that the conditional variance equation of stock returns is useful to capture the autoregressive heteroscedasticity of the stock returns in some markets, except South Korea and Vietnam. In addition, Panel B shows that the exchange rate model in Malaysia, South Korea and Taiwan is not suitable. These results indicate, for GARCH $(1,1)$ with additional variables specified, that the stock model does properly capture the serial correlation and autoregressive heteroskedasticity behavior of the stock returns, but it does not include otherwise, China (which is compared with Thailand) is not suitable.

We choose the model of Table 8 from the Ljung-Box statistics given $\mathrm{Q}(5)$ and $\mathrm{Q}(11)$ are based on chi-squared distributions with 5 and 11 degrees of freedom for all models. The Ljung-Box statistics for the squared standardized shocks have a significant effect. In this table, the stock returns and exchange rate returns have no significant serial correlation, and so all countries are adequate for employing the GARCH $(1,1)$ model.

\section{Conclusion}

China has experienced rapid economic development in recent years, and its huge trade surplus has increased the pressure for the Renminbi's appreciation. Asian emerging countries have also become increasingly reliant on China's market, which is currently the world's second-largest economy. Therefore, China plays a critical role in influencing the economic conditions of many countries in Asia. Research on the return and volatility transmission mechanisms and dynamic correlations among these markets is necessary and important for making decisions related to the movements of stock prices and exchange rates in China and other Asian countries in the research sample.

Table 8. Diagnostic statistics

Panel A: Stock returns in diagnostic statistic of $\operatorname{GARCH}(1,1)$

\begin{tabular}{lllllllll}
\hline & China & India & China & Malaysia & China & Philippines & China & Singapore \\
\hline $\mathrm{Q}(5)$ & 5.1202 & 14.2328 & 8.1562 & 4.0710 & 7.8737 & 14.8869 & 7.3716 & 2.4380 \\
& $(0.4014)$ & $(0.0142)$ & $(0.1478)$ & $(0.5392)$ & $(0.1633)$ & $(0.1109)$ & $(0.1944)$ & $(0.7858)$ \\
$\mathrm{Q}(11)$ & 11.9008 & 21.7442 & 15.6049 & 5.5866 & 15.3539 & 22.1175 & 14.6618 & 7.4034 \\
& $(0.3711)$ & $(0.0264)$ & $(0.1564)$ & $(0.8995)$ & $(0.1669)$ & $(0.0242)$ & $(0.1985)$ & $(0.7655)$ \\
$\mathrm{Q}^{2}(5)$ & 2.9971 & 2.4828 & 1.2260 & 1.2824 & 1.0653 & 0.2072 & 0.9938 & 5.5105 \\
& $(0.7004)$ & $(0.7791)$ & $(0.9424)$ & $(0.9367)$ & $(0.9571)$ & $(0.9990)$ & $(0.9631)$ & $(0.3568)$ \\
$\mathrm{Q}^{2}(11)$ & 6.1116 & 7.0877 & 2.6970 & 1.4134 & 2.5697 & 0.5283 & 2.3320 & 6.6556 \\
& $(0.8658)$ & $(0.7919)$ & $(0.9942)$ & $(0.9997)$ & $(0.9953)$ & $(1.0000)$ & $(0.9969)$ & $(0.8262)$ \\
\hline & China & Taiwan & China & Thailand & China & Vietnam & China & South Korea \\
\hline $\mathrm{Q}(5)$ & 8.1376 & 8.3483 & 7.8370 & 7.9876 & 6.2683 & 6.2683 & 8.0404 & 7.3302 \\
& $(0.1488)$ & $(0.1381)$ & $(0.1654)$ & $(0.1569)$ & $(0.2810)$ & $(0.2810)$ & $(0.1540)$ & $(0.1972)$ \\
$\mathrm{Q}^{(11)}$ & 15.1570 & 14.5610 & 15.5032 & 20.3182 & 13.7697 & 13.7697 & 15.2703 & 11.4250 \\
& $(0.1754)$ & $(0.2035)$ & $(0.1606)$ & $(0.1412)$ & $(0.2460)$ & $(0.2460)$ & $(0.1705)$ & $(0.4084)$ \\
$\mathrm{Q}^{2}(5)$ & 1.1682 & 7.9130 & 1.2115 & 0.3456 & 1.1360 & 143.8168 & 1.2209 & 12.8150 \\
& $(0.9479)$ & $(0.1611)$ & $(0.9438)$ & $(0.9967)$ & $(0.9509)$ & $(0.1200)$ & $(0.9429)$ & $(0.1252)$ \\
$\mathrm{Q}^{2}(11)$ & 2.7142 & 12.4720 & 2.6772 & 0.6675 & 2.4945 & 159.8681 & 2.7121 & 23.4695 \\
& $(0.9940)$ & $(0.3292)$ & $(0.9943)$ & $(1.0000)$ & $(0.9959)$ & $(0.1210)$ & $(0.9940)$ & $(0.1152)$ \\
\hline
\end{tabular}

Note: *,**, and $* * *$ indicates significance at the $10 \%, 5 \%$, and $1 \%$ levels, respectively. 
Panel B: Exchange rate returns in diagnostic statistic of GARCH $(1,1)$

\begin{tabular}{llllllllll}
\hline & China & India & China & South Korea & China & Malaysia & China & Philippines \\
\hline $\mathrm{Q}(5)$ & 18.8339 & 9.2361 & 18.5729 & 31.8756 & 18.7447 & 98.2985 & 19.0734 & 20.3150 \\
& $(0.1121)$ & $(0.1000)$ & $(0.1023)$ & $(0.1145)$ & $(0.1021)$ & $(0.1000)$ & $(0.1119)$ & $(0.1011)$ \\
$\mathrm{Q}(11)$ & 47.3792 & 14.1419 & 47.5166 & 45.2921 & 48.3055 & 128.4388 & 48.0592 & 25.5141 \\
& $(0.1110)$ & $(0.2252)$ & $(0.1010)$ & $(0.1130)$ & $(0.1000)$ & $(0.1000)$ & $(0.1110)$ & $(0.1077)$ \\
$\mathrm{Q}^{2}(5)$ & 0.6406 & 0.5449 & 0.6318 & 36.8748 & 0.6350 & 9.4479 & 0.5780 & 3.0833 \\
& $(0.9861)$ & $(0.9904)$ & $(0.9865)$ & $(0.9544)$ & $(0.9863)$ & $(0.0925)$ & $(0.9890)$ & $(0.6871)$ \\
$\mathrm{Q}^{2}(11)$ & 3.5675 & 1.6272 & 3.4523 & 45.3259 & 3.3818 & 52.8906 & 3.3545 & 4.0272 \\
& $(0.9809)$ & $(0.9994)$ & $(0.9833)$ & $(0.9427)$ & $(0.9847)$ & $(0.0900)$ & $(0.9852)$ & $(0.9691)$ \\
\hline & China & Taiwan & China & Thailand & China & Vietnam & China & Singapore \\
\hline $\mathrm{Q}(5)$ & 20.5653 & 6.1773 & 18.5859 & 101.9873 & 15.7047 & 187.2164 & 21.9165 & 65.5924 \\
& $(0.1010)$ & $(0.2893)$ & $(0.1023)$ & $(0.1100)$ & $(0.1177)$ & $(0.1954)$ & $(0.1005)$ & $(0.1000)$ \\
$\mathrm{Q}^{(11)}$ & 48.1648 & 12.9346 & 47.6750 & 289.6206 & 38.7281 & 234.6618 & 53.2881 & 76.1644 \\
& $(0.1000)$ & $(0.2976)$ & $(0.1113)$ & $(0.1054)$ & $(0.1101)$ & $(0.1240)$ & $(0.1000)$ & $(0.1000)$ \\
$\mathrm{Q}^{2}(5)$ & 0.6070 & 33.0587 & 0.6396 & 3.7063 & 0.5409 & 8.3480 & 0.7565 & 6.4561 \\
& $(0.9877)$ & $(0.0177)$ & $(0.9861)$ & $(0.5924)$ & $(0.9905)$ & $(0.1381)$ & $(0.9797)$ & $(0.2643)$ \\
$\mathrm{Q}^{2}(11)$ & 4.3238 & 39.5224 & 3.4567 & 5.4509 & 2.9336 & 12.9406 & 4.3824 & 14.8484 \\
& $(0.9595)$ & $(0.0117)$ & $(0.9832)$ & $(0.9074)$ & $(0.9916)$ & $(0.2972)$ & $(0.9574)$ & $(0.1895)$ \\
\hline
\end{tabular}

Note: *, **, and $* * *$ indicates significance at the $10 \%, 5 \%$, and $1 \%$ levels, respectively.

Our results show that the China stock market does have a greater positive impact on the other Asian stock markets. We also find that the exchange rate movements of China have a positive effect upon the exchange rate markets of Singapore, South Korea, and Taiwan, but have no significant influence on the other countries. The test of volatility spillover shows that stock market movements do not affect exchange rate markets, which is a result that does not support Phylaktis and Ravazzolo (2005)'s evidence that stock market movements influence the exchange rate dynamics.

\section{References}

Aggarwal R. (1981). Exchange rates and stock prices: a study of the US capital markets under floating exchange rates. Akron Business and Economic Review, 12, 7-12.

Ahearne AG, Fernald JG, Loungani P, Schindler JW. (2003). China and emerging Asia: comrades or competitors? FRB International Working Paper, No. 789.

Bhattacharya B, Mukherjee J. (2003). Causal relationship between stock market and exchange rate, exchange rate reserves and value of trade balance: A case study for India", Paper presented at the 5th Annual Conference on Money and Finance in the Indian Economy, January 2003.

Bollerslev T, Wooldridge JM. (1992). Quasi-maximum likelihood estimation and inference in dynamic models with time-varying covariance. Economic Reviews, 11, 143-172. http://dx.doi.org/10.1080/07474939208800229

Chiang TC, Yang SY. (2003). Foreign exchange risk premiums and time-varying equity market risks. International Journal of Risk Assess Management, 4(4), 310-331. http://dx.doi.org/10.1504/IJRAM.2003.003828

Chkili W, Nguyen DK. (2014). Exchange rate movements and stock market returns in a regime-switching environment: evidence for BRICS countries. Research in International Business Finance, 31, 46-56. http://dx.doi.org/10.1016/j.ribaf.2013.11.007

Chow EH, Lee WY, Solt MS. (997). The exchange rate risk exposure of asset returns. Journal of Business, 70 , 105-123. http://dx.doi.org/10.1086/209710 
Engle R. (2002). Dynamic conditional correlation: a simple class of multivariate generalized autoregressive conditional heteroscedasticity models. Journal of Business and Economic Statistics, 20, 339-350. http://dx.doi.org/10.1198/073500102288618487

Giovannini A, Jorion P. (1987). Interest rates and risk premium in the stock market and in the exchange rate market. Journal of International Money and Finance, 6, 107-124. http://dx.doi.org/10.1016/0261-5606(87)90016-7

Jorion P. (990). The exchange rate exposure of U.S. multinationals. Journal of Business, 63, 331-345. http://dx.doi.org/10.1086/296510

Kanas A. (2000). Volatility spillover between stock returns and exchange rate changes: International evidence. Journal of Business Finance and Accounting, 27(3), 447-467. http://dx.doi.org/10.1111/1468-5957.00320

Moorea T, Wang P. (2014). Dynamic linkage between real exchange rates and stock prices: Evidence from developed and emerging Asian markets. International Review of Economics and Finance, 29, 1-11. http://dx.doi.org /10.1016/j.iref.2013.02.004

Ogawa E, Sakane M. (2006). The Chinese Yuan after the China exchange rate system reform. RIETI Discussion Paper Series, 19, 1-22.

Pan MS, Fok RCW, Liu YA. (2007). Dynamic linkages between exchange rates and stock prices: evidence from East Asian markets. International Review of Economics and Finance, 16(4), 503-520. http://dx.doi.org/10.1016/j.iref.2005.09.003

Phylaktis K, Ravazzolo F. (2005). Stock prices and exchange rate dynamics. Journal of International Money and Finance, 24, 1031-1053. http://dx.doi.org/10.1016/j.jimonfin. 2005.08. 001

Riasi A. (2015). Competitive advantages of shadow banking industry: An analysis using Porter diamond model. Business Management and Strategy, 6(2), 15-27. http://dx.doi.org /10.5296/bms.v6i2.8334

Riasi A, Aghdaie SF. (2013). Effects of a hypothetical Iranian accession to the world trade organization on Iran's flower industry. Consilience: The Journal of Sustainable Development, 10(1), 99-110. http://dx.doi.org/10.7916/D8HQ3ZK8

Roll R. (1992). Industrial structure and the comparative behavior of international stock markets indices. Journal of Finance, 47, 3-41. http://dx.doi.org/10.1111/j.1540-6261.1992.tb03977.x

Smyth R, Nandha M. (2003). Bivariate causality between exchange rates and stock prices in South Asia. Applied Economics Letters, 10, 699-704. http://dx.doi.org/10.1080/1350485032000133282

Solnik B. (1987). Using financial prices to test exchange rate models: A note. Journal of Finance, 42, 141-149. http://dx.doi.org/10.1111/j.1540-6261.1987.tb02555.x

Sui L, Sun L. (2016). Spillover effects between exchange rates and stock prices: Evidence from BRICS around the recent global financial crisis. Research in International Business and Finance, 36, 459-471. http://dx.doi.org /10.1016/j.ribaf.2015.10.011

Yang SY, Doong SC. (2004). Price and volatility spillovers between stock prices and exchange rates: Empirical evidence from the G-7 countries. International Journal of Business and Economics, 3(2), 139-153.

Zhao H. (2010). Dynamic relationship between exchange rate and stock price: Evidence from China. Research in International Business and Finance, 24(2), 103-112. http://dx.doi.org /10.1016/j.ribaf.2009.09.001

\section{Notes}

Note 1. Aggarwal (1981), Giovannini and Jorion (1987), and Roll (1992) indicate that the two markets exhibit a significantly positive relationship. However, Soenen and Hennigar (1988) find a significantly negative relationship, and Solnik (1987), Chow et al. (1997), and Bhattacharya and Mukherjee (2003) show that the relationship is not significant. 